\title{
LDHs as Adsorbents of Phenol and Their Environmental Applications
}

\author{
Butenko E. ${ }^{1, *}$, Malyshev A. ${ }^{2}$, Kapustin A. ${ }^{1}$ \\ ${ }^{1}$ Azov Sea State Technical University, Mariupol, Ukraine \\ ${ }^{2}$ SASOL Germany GmbH \\ *Corresponding author: butenkoeo@rambler.ru
}

Received January 27, 2014; Revised February 15, 2014; Accepted February 17, 2014

\begin{abstract}
Developed a method of synthesis of layered double hydroxides (LDH) of different composition. The investigations the processes of adsorption of phenols on LDH variable composition. Were designed kinetic parameters the processes of adsorption of phenols.
\end{abstract}

Keywords: layered double hydroxides, phenols adsorption

Cite This Article: Butenko E., Malyshev A., and Kapustin A., "LDHs as Adsorbents of Phenol and Their Environmental Applications." American Journal of Environmental Protection, vol. 2, no. 1 (2014): 11-15. doi: 10.12691/env-2-1-3.

\section{Introduction}

At the present an increase of phenol and its derivatives concentration in the environment takes place, due to discharge it into the water from inadequately treated wastewater of different enterprises, especially coke and petrochemical enterprises [1]. Phenol can cause different diseases of organisms, including humans. Phenol is particularly dangerous because of its relatively good solubility in water.

To reduce the penetration of phenol into the environment may take place primarily due to the effective treatment of industrial wastewater, in which the phenol and its derivatives are found.

There are various methods of purification of industrial waste waters from the dissolved phenol. Liquid extraction is used for the purification of waste water containing phenols [2]. The feasibility of wastewater treatment through extraction is determined by the concentration of organic impurities. Extraction of phenols from wastewater is economically inefficient process, because of use of costly ethers and esters for the extraction of phenols from wastewater.

The radiation treatment is used to remove phenol from wastewater. During the $\gamma$-radiation $\left(\mathrm{Co}^{50}, \mathrm{Cs}^{137}\right)$ oxidation and polymerization of organic and inorganic substances (including not biodegradable and toxic compounds) takes place. The deposition of colloidal and suspended solids, disinfection and deodorization take place too. Radiation treatment, as a fast single-stage process gives the complex effect [3].

$\mathrm{Co}^{60} \gamma$-irradiation of aqueous solutions containing 10 $\mathrm{mg} / \mathrm{l}$ of phenol in a flow system with a dose of $0,48 \mathrm{~W} / \mathrm{kg}$ for 20 min completely decomposes it to water and carbon dioxide, the decomposition rate is $0.25 \mathrm{mg} /(\mathrm{l} \mathrm{min})$.
However, through radiation treatment the removal of phenol and its derivatives up to the level of MPC is not achieved.

The final purification achieving MPC $(0.1 \mathrm{~g} / \mathrm{l})$ is only under the use of adsorption technology possible. Adsorption methods are widely used for wastewater treatment from dissolved organic substances. The advantage of this method is its high efficiency, and the possibility of sewage directly from many toxic substances. The effectiveness of adsorption reaches 80-95 \%, depending on the nature of the adsorbent, the adsorption surface and its accessibility, on the chemical structure of substance and its state in solution [4].

Most of all, activated carbons [5] are used as a sorbent for the removal of phenols. However, their use is limited by their high cost. In addition, the sorption process on activated carbon are physical process, the sorbed ions are not associated with a matrix by chemical bonds, which makes the disposal process risky due to the possible of the reverse process of desorption. Also, carbon sorbents have disadvantages such as long-term establishment of sorption equilibrium and the low degree of sorption.

The most promising sorbents are the sorbents based on clays, synthetic and natural [6]. They are cheap, accessible and efficient, universal sorbents, and they have a high absorption capacity, resistance to environmental influences and can serve as excellent carriers for mounting on the surface of various compounds at their modification.

The aim of our work is the search for new anionic sorbents, the use of which would allow effective remove of phenols from wastewater.

For this aim LDHs with variable composition were investigated, and their physical-chemical- as well adsorption properties were studied. Also we studied the kinetics of ion-exchange sorption of phenol on the LDHs of different composition, the structure of LDHs and its changes during the phenol sorption. 


\section{Experimental Section}

Synthesis of layered double hydroxides was carried out by the method described in $[7,8]$. Samples were kindly provided by SASOL Germany GmbH.

The obtained sorbents have the following characteristics (Table 1).

Table 1. The characteristics of layered double hydroxides

\begin{tabular}{|c|c|c|c|c|}
\hline $\mathrm{Mg} / \mathrm{Mg}+\mathrm{Al}, \mathrm{mol} / \mathrm{mol}$ & 0.52 & 0.72 & 0.81 & 0.86 \\
\hline $\mathrm{d}, \AA$ & 3.038 & 3.036 & 3.045 & 3.058 \\
\hline $\mathrm{c}, \AA$ & 22.62 & 22.67 & 22.81 & 23.40 \\
\hline Specific surface area, $\mathrm{m}^{2} / \mathrm{g}$ & 250 & 200 & 192 & 180 \\
\hline Pore volume, $\mathrm{ml} / \mathrm{g}$ & 0.5 & 0.2 & 0.2 & 0.2 \\
\hline Acidity, meq/g & 0.41 & 0.32 & 0.21 & 0.06 \\
\hline Basicity, meq/g & 0.73 & 0.54 & 0.63 & 0.85 \\
\hline $\mathrm{E}_{\text {din., }}$ meq/g & 0.075 & 0.081 & 0.041 & 0.036 \\
\hline $\mathrm{E}_{\text {stat. }}, \mathrm{meq} / \mathrm{g}$ & 0.38 & 0.41 & 0.10 & 0.08 \\
\hline
\end{tabular}

The resulting LDHs were investigated to determine the surface basicity.

Determination was carried out by titration in the presence of Hammett indicators [9]. Analysis were carried out by the following procedure. In a glass beaker $(20 \mathrm{ml})$, mounted on a magnetic stirrer was placed a sample of a layered double hydroxide, and then a glass was filled with benzene. Then a glass cylinder, divided by a porous partition with a standard sample on it was placed in the beaker. Hammett indicator was added into benzene, and the color change can be observed on the surface of a standard sample. The followed indicators were used: bromothymol blue ( $\mathrm{pKa}=7.2)$, 2-chloro-4-nitroaniline $(\mathrm{pKa}=17.2)$, 4-chloroaniline $(\mathrm{pKa}=26.5), 2,4,6-$ trinitroanilin ( $\mathrm{pKa}=12$ and 2), 2,4-dinitroaniline ( $\mathrm{pK}=$ 15.0), 4-nitroaniline ( $\mathrm{pKa}=18.4)$. Calcined $\mathrm{MgO}$ was used as a comparison standard.

Structure of LDHs was studied by X-ray diffraction (Figure 1). The X-ray diffraction experiments were performed using a SIEMENS D-500 diffractometer with Co K $\alpha$ - radiation. Special computer programs were used for smoothing, background correction and decomposition of overlapped diffraction peaks.

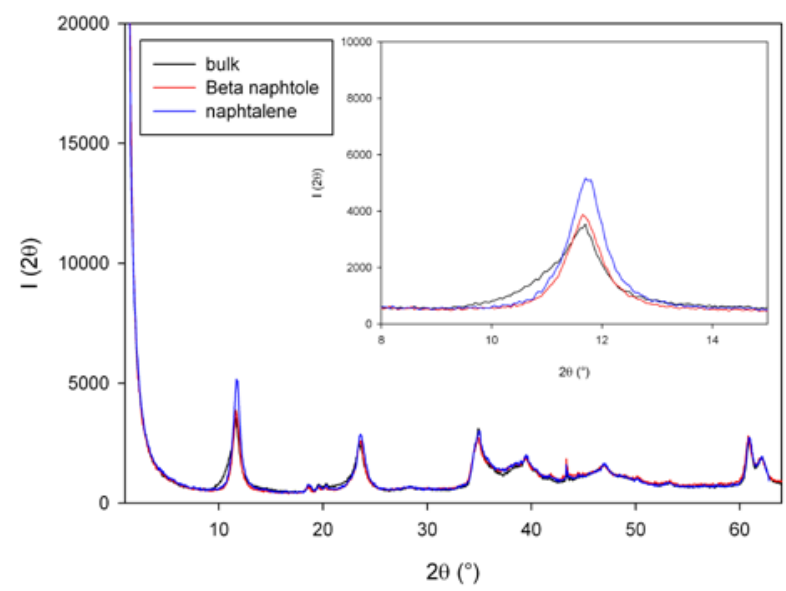

Figure 1. XRD patterns of $\mathrm{LDH} \mathrm{Mg} /(\mathrm{Mg}+\mathrm{Al})=0,72 \mathrm{~mol} / \mathrm{mol}$ (asprepared, with naphthalene, with $\beta$-naphtol)

X-ray fluorescence spectroscopy (XRF), Shimadzu XRF-1700 sequential XRF spectrometer was used to determine the $\mathrm{Mg} / \mathrm{Al}$ atomic ratios of the samples.
The nitrogen adsorption-desorption isotherms were recorded at $77 \mathrm{~K}$ on a Coulter SA 3100 automated gas adsorption system on samples previously degassed at 383 $\mathrm{K}$ for $7 \mathrm{~h}$ under vacuum. Specific surface areas (S-BET) were determined using the Brunauer-Emmett Teller (BET) method on the basis of adsorption data. The pore volume $(\mathrm{Vp})$ values were determined by using the t-plot method of De Boer.

Thermal behavior was studied by thermo-analytical methods, the samples calcined on the air (the temperature was raised with $10 \mathrm{~K} / \mathrm{min}$ to $1273 \mathrm{~K}$ ).

The concentration of phenols was determined photometrically through the reaction of formation of the colored compound with 4-aminoantipyrine in an alkaline medium $(\mathrm{pH}=10)$ in the presence of ammonium persulfate. The concentration of alcohol, naphthalene and $\beta$-naphthol was determined by chromatography on a chromatograph HP 5890.

Sorption studies were performed in periodic conditions, loading the sorbent in a solution containing sorbed substances (alcohols, phenols, naphthalene derivatives), and samples were taken after vigorous mixing for some time.

\section{Results and Discussion}

LDHs are products of isomorphic substitution of metal cations in the hydroxides of metal cations of higher oxidation degree [13], as shown in Figure 2.

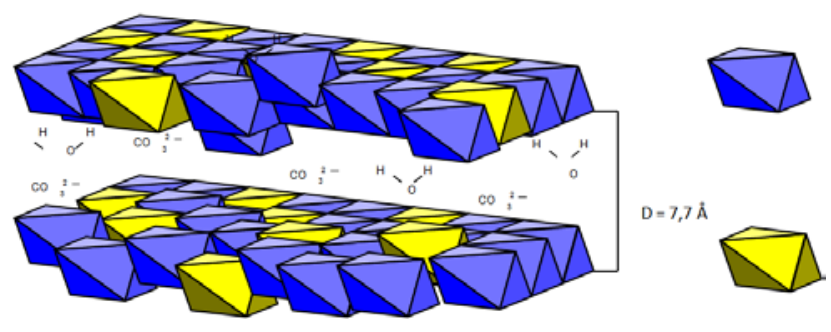

Figure 2. - Structure of layered double hydroxides

The acid properties of phenol are beneficial for using of LDHs for the phenol adsorption is. Studying LDHs, unlike most natural clays, are not solid bases, not acids. The basic site in such compounds may be represented by a hydroxyl group, which is localized at the tetrahedral aluminum. Lewis basic sites are a lone electron pair of oxygen:<smiles>[O-][Al]([O-])([O-])O</smiles>

Bronsted site<smiles></smiles>

Lewis site
The presence of the basic sites of Brønsted and Lewis types allows the process of anion exchange in the inner space of layered double hydroxides. The anion-exchange reaction for phenol and its derivatives on layered double hydroxides proceeds as follows:

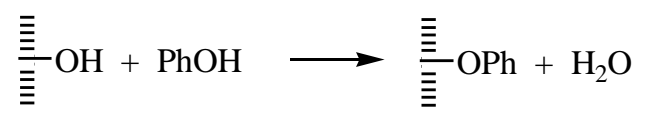

Since phenol is an acid, so the represented reaction of anion exchange takes place almost irreversibly. In addition, 
phenol is a rather strong organic acid, so the process of ion-exchange takes place very quickly.

To determine the process parameters of sorption of phenols on LDH kinetic studies were carried out. Conducting of kinetic studies under the conditions far from the sorption equilibrium was predetermined by the fact that in real industrial conditions the sorption processes in exactly non-equilibrium conditions. The study was carried out in the mixed reactor with periodic feeding, the concentration of phenol was determined by spectrophotometry. The obtained data are depicted on Figure 3.

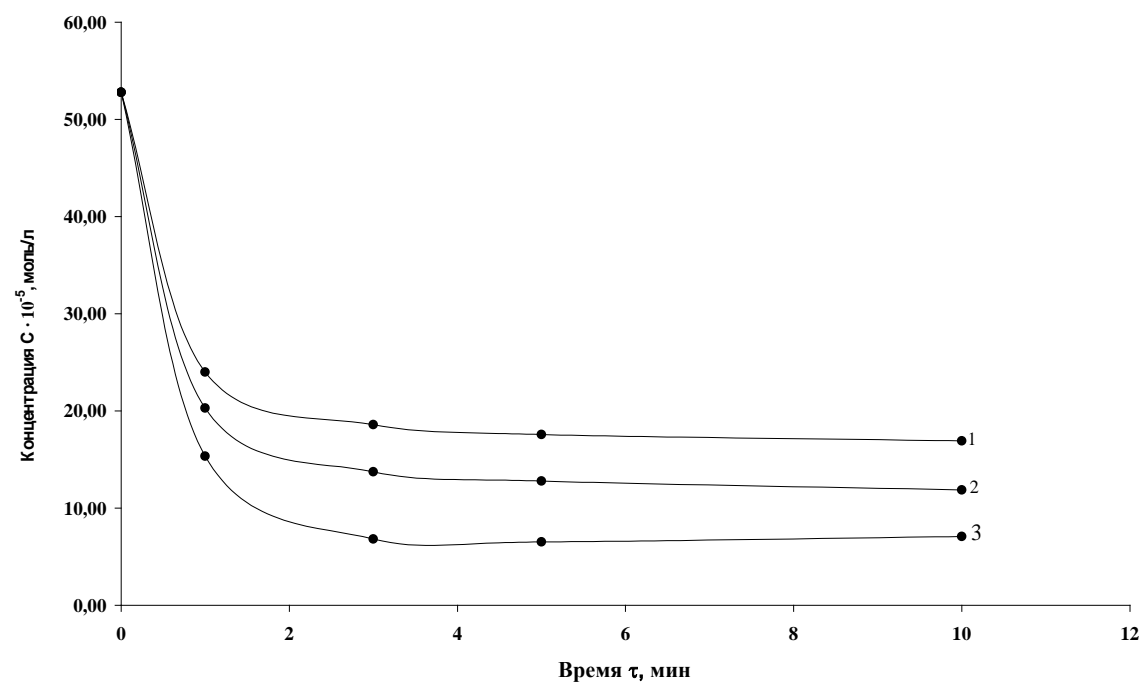

Figure 3. Changing the phenol concentration $\mathrm{ft}$ time at different mass of sorbent: $1-0.1 \mathrm{~g}, 2-0.15 \mathrm{~g}, 3-0.2 \mathrm{~g} ;\left(\mathrm{Mg} /(\mathrm{Mg}+\mathrm{Al})=0.72 \mathrm{~mol} / \mathrm{mol}, \mathrm{t}=20^{\circ} \mathrm{C}\right)$

At the initial moment, at high degree of conversion, the experimental results are well linearizing in the $\ln \left(\mathrm{c}_{\mathrm{o}} / \mathrm{c}\right)-\tau$ coordinates (Figure 4), indicating the first order on adsorbate concentration.

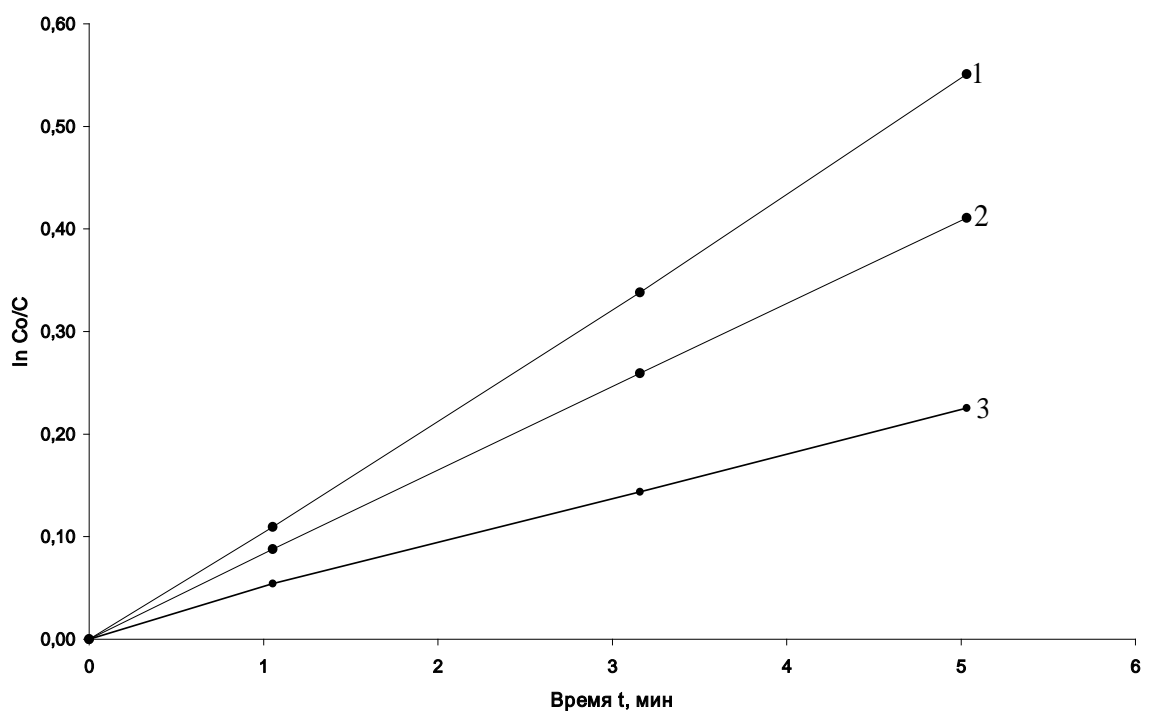

Figure 4. - Dependence of $\ln \left(\mathrm{c}_{\mathrm{o}} / \mathrm{c}\right)$ on the sorption time, $1-0.1 \mathrm{~g}, 2-0.15 \mathrm{~g}, 3-0.2 \mathrm{~g} ;\left(\mathrm{Mg} /(\mathrm{Mg}+\mathrm{Al})=0.72 \mathrm{~mol} / \mathrm{mol}, \mathrm{t}=20^{\circ} \mathrm{C}\right)$

Investigation of the kinetics of the reaction showed that the rate of sorption depends on the concentration of phenol and amount of LDHs. To replace the mass of the sorbent on the concentration of active sites $\left(\mathrm{C}_{\mathrm{as}}\right)$ in a volume of solution used the values of the dynamic capacity of LDHs, defined in dynamic conditions (Table 2).

Table 2. The dynamic capacity of LDHs (phenol)

\begin{tabular}{|c|c|c|c|c|}
\hline $\mathrm{Mg} /(\mathrm{Mg}+\mathrm{Al}), \mathrm{mol} / \mathrm{mol}$ & 0.52 & 0.72 & 0.81 & 0.86 \\
\hline E, meq $/ \mathrm{g}$ & 0.18 & 0.31 & 0.36 & 0.46 \\
\hline
\end{tabular}

The kinetic equation of sorption of phenol is as follows:

$$
\vartheta=k \cdot C_{\mathrm{PhOH}} \cdot C_{a s}
$$

We investigated the adsorption capacity of phenol in reactions with sorbents with varying degrees of isomorphous substitution. Rate constants for phenol sorption for sorbents with different molar ratio of $\mathrm{Mg} /$ $(\mathrm{Mg}+\mathrm{Al})$ have been calculated. The obtained values of the constants are presented in Table 3.

Table 3. Second order constants of sorption

\begin{tabular}{|c|c|c|c|c|}
\hline $\mathrm{Mg} /(\mathrm{Mg}+\mathrm{Al}), \mathrm{mol} / \mathrm{mol}$ & 0.52 & 0.72 & 0.81 & 0.86 \\
\hline$k \cdot 10^{3}, \mathrm{l} / \mathrm{mol} \cdot \mathrm{s}$ & 0.83 & 1.29 & 1.67 & 1.70 \\
\hline
\end{tabular}

To determine the activation parameters of sorption of phenols on LDHs, the ion exchange at different temperatures has been studied. These data are presented as curves on Figure 5. 


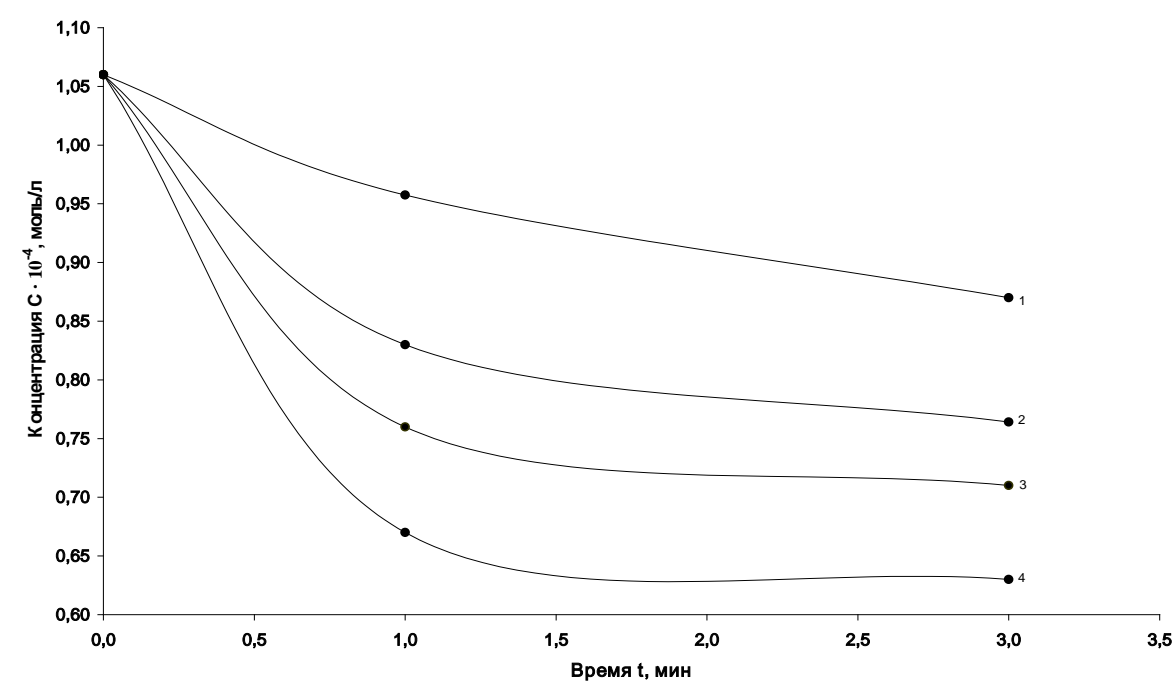

Figure 5. Changing of phenol concentration in time at different temperatures; $1-21^{\circ} \mathrm{C}, 2-40^{\circ} \mathrm{C}, 3-60^{\circ} \mathrm{C}, 4-75^{\circ} \mathrm{C}$

Since the reaction of a rather strong organic acid with a solid base proceeds quickly, the linearization performed at the initial moment of reaction. The rate constants of sorption of phenol at different temperatures were determined. The obtained data are presented in Table 4.

Table 4. The value of the rate constants of the sorption at different temperatures

\begin{tabular}{|c|l|l|l|c|}
\hline $\mathrm{T}, \mathrm{K}$ & 294 & 313 & 333 & 348 \\
\hline $\mathrm{k}, \mathrm{s}^{-1}$ & 0.08 & 0.24 & 0.33 & 0.46 \\
\hline \multicolumn{3}{|c|}{$\mathrm{E}=29.1 \mathrm{~kJ} / \mathrm{mol}$} & $\mathrm{k}_{\mathrm{o}}=9.9 \cdot 10^{3} \mathrm{l} / \mathrm{mol} \cdot \mathrm{s}$ \\
\hline
\end{tabular}

Dependence of the rate of phenol sorption on the temperature has been investigated only for the sorbent $\mathrm{Mg} /(\mathrm{Mg}+\mathrm{Al})=0,72 \mathrm{~mol} / \mathrm{mol}$, however, we can assume that for other sorbents will be observed a similar dependence.

The full kinetic equation for the phenol sorption of phenol sorbent has the form:

$$
\mathrm{k}=\mathrm{k}_{o}=9.9 \cdot 10^{3} \cdot e^{-29,1 / \mathrm{RT}}
$$

The obtained value of activation energy suggests that the reaction proceeds in the diffusion region, but close enough to the kinetic region, due to the high acidity of phenol.

The reaction with phenol proceeds rapidly and after 1520 minutes the dynamic equilibrium set. Due to the high acidity of phenol the equilibrium is strongly shifted toward the formation of products, the reaction proceeds to completion.

However, if at the end of the sorption to leave the LDHs in a solution of phenol in a long time (48 hours), the degree of adsorption increases, a simultaneous increase the inter-planar distance from 3,03 to 5,76 $\AA$. By our assumption, this is due to the reorientation of the aromatic rings in the inner space of LDHs (Figure 6), with increased availability of active sites.
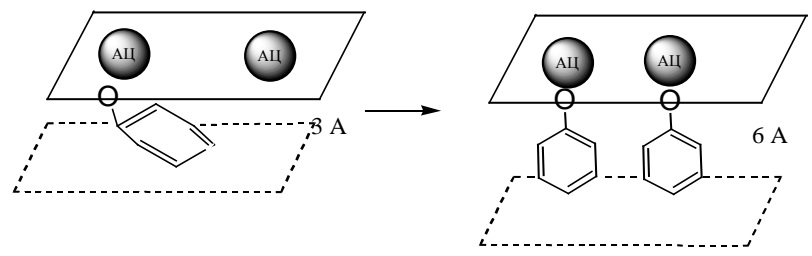

Figure 6. Change the location of the molecules of phenol in the LDHs

\section{Conclusions}

1. Physical-chemical properties of LDHs. It has shown that changing the composition of $\mathrm{LDH}$ the concentration and strength of active sites on their surface can be regulated, and thus we can regulate the sorption properties.

2. The kinetics of phenol adsorption on the LDH of variable composition have been studied.

3. The dependence of the kinetic parameters of the adsorption on the composition of LDHs has been shown.

4. The kinetic and activation parameters of the sorption of phenol on the LDHs, which may be the basis for the calculation of process plants for the removal of phenols from industrial wastewater, have been determined.

\section{References}

[1] Rubio J. Overview of flotation as a wastewater treatment technique / J. Rubio, M. Souza, R. Smith //Minerals Engineering. 2002. Vol. 15, P. 139-155.

[2] Яковлев. С.В. Современные решения по очистке природных и сточных вод / Яковлев. С.В., Демидов О.В. // Экология и промышленность России. 1999. № 12. С. 12-15.

[3] Куркуленко С.С. Состояние обращения с отходами в Донецкой области / С.С. Куркуленко, Г.И. Бородай // Регион: проблемы и перспективы. 2002. Т. 8. С. 20-23.

[4] Roostaei N. Removal of phenol from aqueous solutions by adsorption. / N. Roostaei, F. Handan Tezel // Environmental Management, 2004. V. 70. P. 157-164.

[5] Arellano-Cárdenas S. Adsorption of Phenol and Dichlorophenols from Aqueous Solutions by Porous Clay Heterostructure (PCH). / S. Arellano-Cárdenas, T. Gallardo-Velázquez, G. Osorio-Revilla, Ma. del Socorro López-Cortéz1 and B. Gómez-Perea1 // J. Mex. Chem. Soc., 2005.V. 49(3). P. 287-291.

[6] Капустин А.Е. Катализ слоистыми двойными гидроксидами. / А.Е. Капустин // Научные проблемы современной технологии. 2007. № 16. C. 267-275.

[7] Vaccari. A. Layered double hydroxides: present and future / A. Vaccari, V. Rives // Journal of Membrane Science. 2002.Vol. 9. P. 134-138.

[8] Bolongini $\mathrm{M} . \mathrm{Mg} / \mathrm{Al}$ mixed oxides prepared by coprecipitation and sol-gel routes: a comparison of their physico-chemical features and performance in $m$-cresol methylation / M. Bolongini, 
F. Cavani, C. Perego // Microporous and Mesoporous Materials. 2003. V. 66. P 77-89.

[9] Грекова Н.Н. Проблемы индикаторного титрования основных гетерогенных катализаторов / Н.Н. Грекова, О.В. Лебедева, А.Е. Капустин // Катализ и нефтехимия. 1996. № 2. С. 76-79.

[10] Fagerlund G. Determination of specific surface by the BET method / G. Fagerlund //Materials and Structures. 2006. P 239-245.
[11] Грег С.Н. Адсорбция, удельная поверхность, пористость / С.Н. Грег. М., 1990. 504 c.

[12] Крайнов С.Р. Геохимические и экологические последствия изменения химического состава подземных вод под влиянием загрязняющих веществ / С.Р. Крайнов, Г.Ю. Фойгт, В.П. Закутин // Геохимия. 1991. №2. С.169-182.

[13] Капустин А.Е. Неорганические аниониты / А.Е. Капустин// Успехи химии. 1991. Т. 60. № 12. С. 2685-2717. 